\title{
Perancangan Aplikasi Jadwal Konser Musik (Kick Gigs) Berbasis Mobile
}

\author{
Antonius Titis Adhitianto Bintang Timur ${ }^{1)}$, Magdalena A. Ineke Pakereng ${ }^{2)}$ \\ ${ }^{1) 2)}$ Teknik Informatika, Teknologi Informasi, Universitas Kristen Satya Wacana \\ Correspondence author: bintangtimur90an@gmail.com
}

DOI: https://doi.org/10.37012/jtik.v7i2.599

\begin{abstract}
Abstrak
Permusikan di Indonesia kini telah mengalami perkembangan yang pesat dalam beberapa dekade ini. Jadwal konser yang sering digunakan saat ini hanya melalui social media. Seiring perkembangan teknologi, internet memunculkan perubahan ruang kreatifitas musisi dalam menyebarkan informasi panggungnya menjadi lebih mudah. Tujuan dari penelitian ini adalah pembuatan aplikasi jadwal konser live performance agar dapat digunakan untuk mempermudah masyarakat dalam memperoleh informasi jadwal panggung dengan lebih mudah dan cepat. Serta memudahkan musisi dalam menyebarluaskan informasi panggungnya ke masyarakat. Penelitian ini menghasilkan aplikasi jadwal konser bernama Kick Gigs berbasis mobile yang dapat berjalan sesuai dengan apa yang diharapkan yang dibangun menggunakan bahasa pemrograman Dart 2.13 dengan framework flutter 2.0 dan basis data Firestore. Aplikasi Mobile ini diharapkan dapat membantu musisi kecil dalam pengembangan karir musiknya lebih baik lagi. Selain itu dapat membantu pengusaha cafe dan restoran untuk turut berdampingan bersama musisi dalam mengembangkan bisnis dan karya musik dengan pertunjukan live performance yang mengundang lebih banyak lagi pengunjung.
\end{abstract}

Kata Kunci: Flutter, Android, Firebase Storange

\begin{abstract}
Music in Indonesia has now experienced rapid development in recent decades. Concert schedules that are often used today are only through social media. Along with the development of technology, the internet has created a space to create creativity in disseminating stage information more easily. The purpose of this research is to make a live performance concert schedule application so that it can be used to facilitate the public in obtaining stage schedule information more easily and quickly. As well as facilitate musicians in disseminating stage information to the public. This research produces a mobile-based concert schedule application called Kick Gigs that can run as expected, built using the dart 2.13 programming language with the flutter 2.0 framework and the Firestore database. This Mobile Application is expected to help small musicians in developing their music career even better. In addition, it can help cafe and restaurant entrepreneurs to participate with musicians in developing their business and musical works with live performances that invite many visitors.
\end{abstract}

Keywords: Flutter, Android, Firestore, Music 


\section{PENDAHULUAN}

Permusikan di Indonesia kini telah mengalami perkembangan yang pesat dalam beberapa dekade ini. Banyaknya jadwal musik di tiap daerah di Indonesia membuat banyak musisi muncul ke kancah Nasional hingga Internasional. Seiring perkembangan teknologi, internet memunculkan perubahan ruang kreatifitas untuk musisi yang harus selalu berinovasi untuk menghadirkan jadwal konser yang lebih cepat dan mudah ke masyarakat luas.

Internet memiliki peranan penting dalam kemajuan musisi dalam berkarya, dengan adanya Internet, kini semua orang dapat memiliki informasi mengenai jadwal panggung grup band serta musisi didalamnya.

Adanya perkembangan teknologi serta perkembangan dunia digital masa kini memudahkan masyarakat untuk memperoleh informasi dari manapun, dari handphone contohnya. Dengan teknologi, manusia dapat melakukan hal yang sulit menjadi lebih mudah, salah satu perkembangan teknologi yang populer adalah Mobile App. Teknologi Mobile App yang terus diperbaharui, sehingga pengguna dapat mengakses dan mengunggah informasi hanya dalam satu genggaman.

Live performance sekarang ini masih menjadi suatu pertunjukan yang memiliki peran sosial yang penting. Faktor pendukung selain dari sisi musisi, ada juga pemilik café dan restoran. Mereka seringkali mengadakan pertunjukan live music beberapa kali dalam seminggu untuk menarik pelanggan ke tempat mereka [1].

Tujuan dari penelitian ini adalah pembuatan aplikasi jadwal konser live performance yang dapat digunakan seluruh musisi sebagai user dalam aplikasi ini. Adapun aplikasi berbasis mobile yang dibangun memberikan beberapa manfaat seperti mempermudah musisi untuk menyebarluaskan informasi panggungnya ke penikmat musik. Aplikasi ini juga bisa diakses kapanpun dan dimanapun [2]. Selain itu, aplikasi mobile yang dibangun dapat memfasilitasi musisi kecil untuk memperluas jaringan antar musisi yang tersebar di Indonesia [3].

Berdasarkan latar belakang yang ada, maka dilakukan penelitian yang bertujuan untuk membuat suatu Aplikasi Mobile yang dapat membantu masyarakat dalam memperoleh informasi jadwal panggung dengan lebih mudah dan cepat. 


\section{METODE PENELITIAN}

Dalam penelitian ini menerapkan metode SDLC (System Development Life Cycle) dengan model waterfall. Model Waterfall yaitu dengan perancangan suatu sistem informasi yang diterapkan secara sistematik dan sekuensial [8]. Penelitian ini bertujuan untuk membuat sebuah aplikasi Jadwal konser (Kick Gigs). Dalam penelitian ini dibagi menjadi 4 tahapan informasi. Penelitian ini bertujuan untuk membuat sebuah aplikasi Jadwal Konser (Kick Gigs) yang dalam penelitian ini dibagi menjadi 4 tahapan, yaitu, (1) Identifikasi masalah, (2) Perancangan dan desain sistem, (3) Pembangunan sistem, (4) Implementasi dan Pengujian sistem. Pada perancangan sistem informasi menggunakan tahapan penelitian seperti pada Gambar 1.

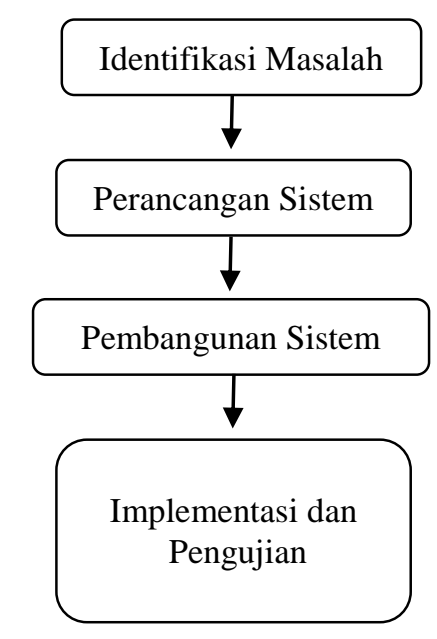

Gambar 1 Tahapan Penelitian

Tahapan awal penelitian adalah identifikasi masalah. Tahapan penulisan mengidentifikasi masalah yang sering terjadi pada kalangan musisi kecil bahwa mereka sangat sulit meramaikan pertunjukan mereka saat Live Performance. Karena kurangnya persebaran informasi yang merata yang biasanya hanya terjadi jika musisi tersebut belum memiliki nama yang besar.

Tahapan kedua dilakukan perancangan aplikasi mobile untuk menjawab permasalahan yang ada musisi kecil dalam aktivitas live performance-nya. Perancangan ini akan menggunakan metode pemodelan yang berorientasi objek yaitu UML. UML adalah Bahasa standar yang banyak digunakan untuk menentukan kebutuhan, menganalisis, dan desain, serta menjelaskan arsitektur pemrograman berorientasi objek di dunia permusikan. UML adalah pemodelan komputer dan Bahasa komunikasi visual yang menggunakan diagram dan dukungan teks serta penggunaan UML tidak hanya terbatas pada satu metode saja, tetap sebagian besar digunakan dalam metodologi berorientasi objek [9]. 
Pada tahap ketiga, dilakukan pembuatan aplikasi yang sudah dirancang pada tahap sebelumnya. Aplikasi ini dibangun dengan basis mobile dengan framework Flutter 2.2, yaitu sebuah Framework yang dikembangkan oleh perusahan teknologi bernama Google.inc yang dapat dikembangkan serta dijalankan pada platform besar Android [6]. Bahasa pemrograman yang dipakai adalah Dart 2.13 menggunakan basis data Firestore.

Use Case dideskripsikan secara tekstual dalam bentuk use case scenario untuk menjelaskan interaksi yang terjadi antara actor dengan sistem. Selanjutnya, use case scenario di ilustrasikan secara visual dalam bentuk use case diagram untuk menggambarkan konteks dari sistem yang dikembangkan[10]. Use Case diagram dibuat sebagai analisa awal membangun suatu aplikasi untuk menjelaskan fungsi secara sederhana dari sudut pandang user. Pada Gambar 2 menjelaskan, seorang user dapat membuat suatu jadwal live performancenya sendiri dengan mudah. Memberikan keterangan waktu, poster, nama Artis/Musisi dan tanggal. Jadi, setiap user akan memiliki hak untuk membuat jadwal live performance nya dengan mudah dan cepat. Jadwal user ini akan ditampung menjadi 1 tempat yakni di kolom Explore

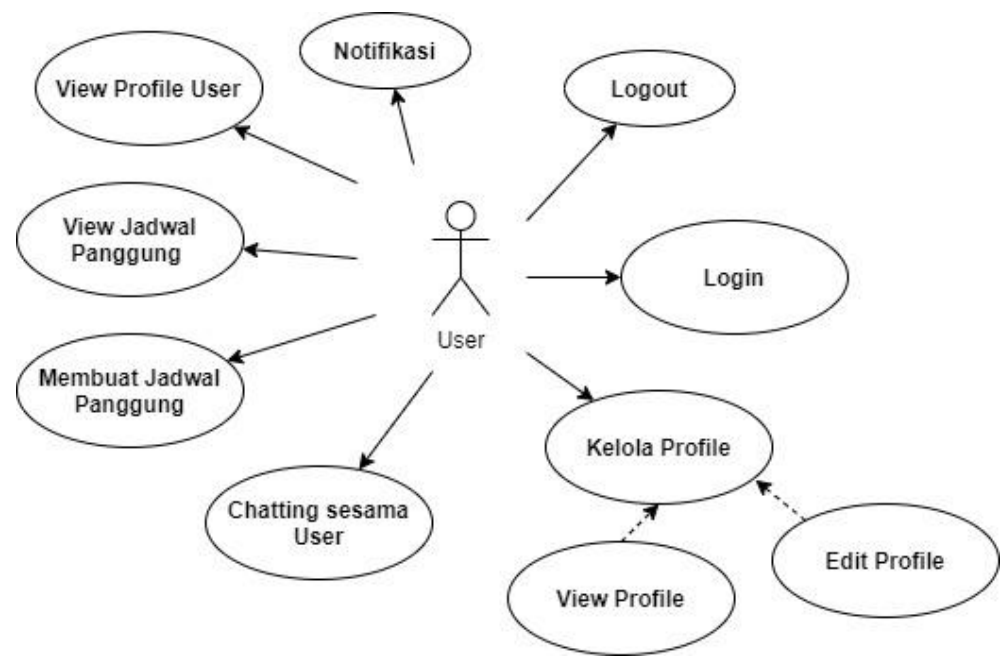

Gambar 2 Use Case Diagram Sistem

Activity Diagram merupakan rancangan aliran kerja dan aktivitas dalam sebuah sistem yang akan dijalankan. Activity Diagram juga digunakan menampilkan proses model sistem. Activity Diagram adalah salah satu yang paling mudah pada UML diagram karena mereka menggunakan simbol-simbol yang mirip dengan notasi flowchart [11]. Activity Diagram ini menggambarkan rangkaian aktivitas dalam sistem yang berjalan pada sistem aplikasi Jadwal Konser Kick Gigs. 


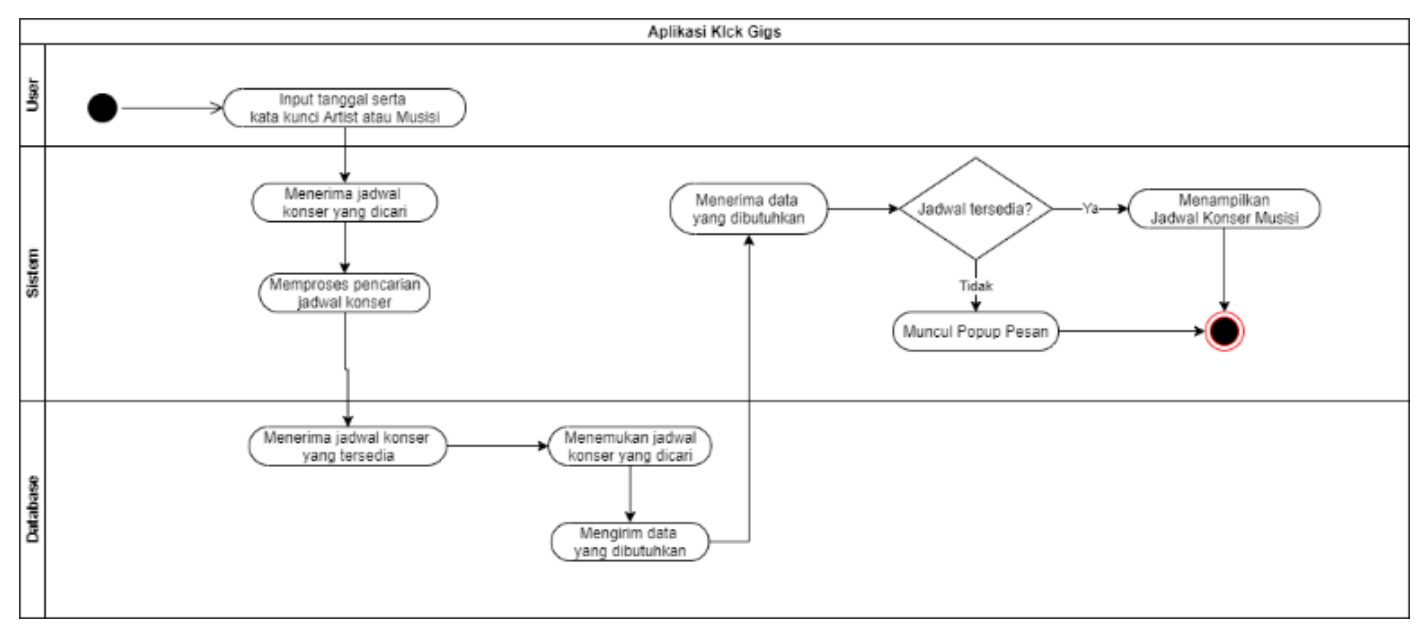

Gambar 3 Activity Diagram Sistem Aplikasi Mobile Kick Gigs

Pada Gambar 3 menunjukan proses diagram alur dari aplikasi mobile Kick Gigs, pada diagram tersebut dijelaskan, pengguna dapat mencari Jadwal Konser favoritnya dengan kata kunci Artis/Musisi beserta tanggal konser itu berlangsung.

Tahap terakhir, aplikasi yang telah selesai dibangun dilakukan pengujian sistem untuk mengetahui apakah aplikasi berhasil berjalan sesuai dengan perancangan yang dilakukan. Pengujian sistem menggunakan metode black box testing yang merupakan salah satu teknik pengujian perangkat lunak. Black box testing digunakan untuk menentukan fungsionalitas dan output suatu sistem. Fokus utama dari pengujian black box adalah menyesuaikan standar program sebuah aplikasi apabila terdapat bug pada program aplikasi tersebut.

\section{HASIL DAN PEMBAHASAN}
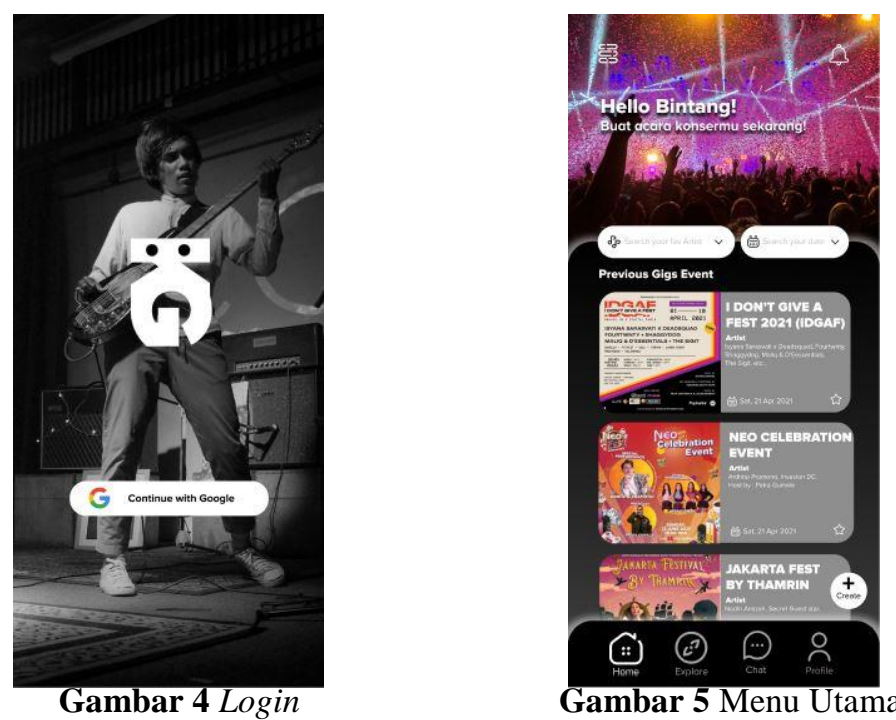
Pada tahap pengimplementasian sistem rancangan yang sudah dibuat, berikut beberapa tampilan aplikasi mobile Kick Gigs yang telah di bangun. Gambar 4 merupakan tampilan halaman form login melalui Google. Pada halaman login ini, user harus mengkoneksikan email google untuk dapat masuk ke dalam menu utama. Gambar 5 merupakan menu utama yang menampilkan jadwal live performance (konser) yang akan dicari user. Terdapat search artist dan tanggal penyelenggaraan event itu akan digelar. Menu utama juga menampilkan "Previous Gigs Event” yang artinya menampilkan event yang sebelumnya sudah selesai digelar.

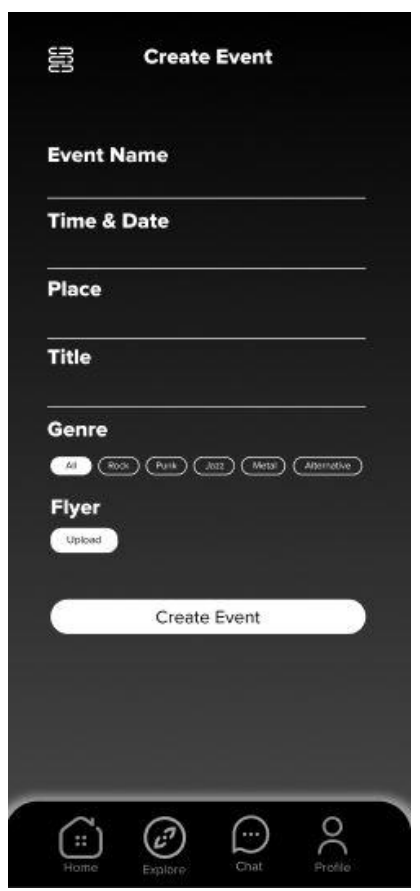

Gambar 6 Create Event

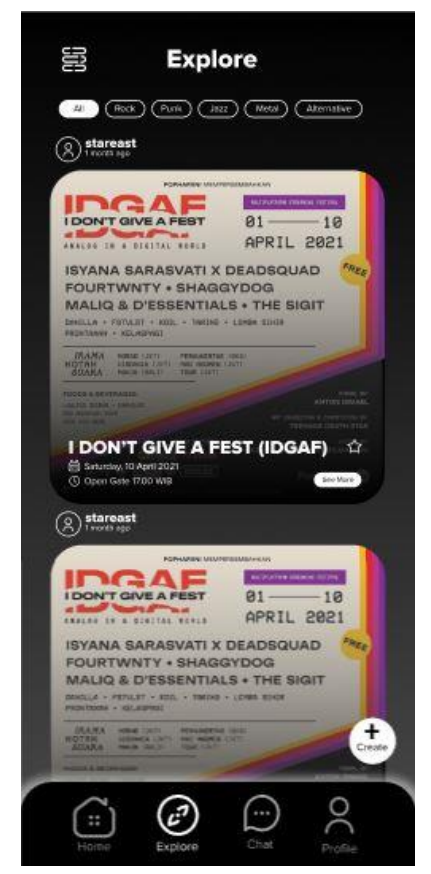

Gambar 7 Menu Utama Explore

Gambar 6 merupakan tampilan dari "Create Event” yakni membuat acara panggung. Fitur ini digunakan musisi untuk memberikan informasi jadwal panggungnya. Tersedia Nama Event, Tanggal, Tempat, dan Caption, Genre, serta Upload Gambar. Gambar 7 merupakan Explore dari aplikasi Kick Gigs. Disini pengguna sekaligus musisi dapat mengetahui jadwal event sesama musisi melalui kolom explore ini. Dalam halaman ini, user bisa melihat explore Aplikasi Kick Gigs dengan filter berdasarkan genre musik. Explore sebagai wadah seluruh data yang diinputkan pada create event dan fitur search Artis/Musisi dengan tanggal di menu Homepage. 


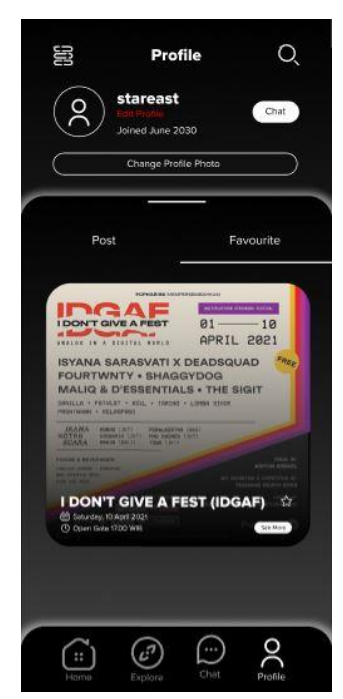

Gambar 8 Menu Utama Profile

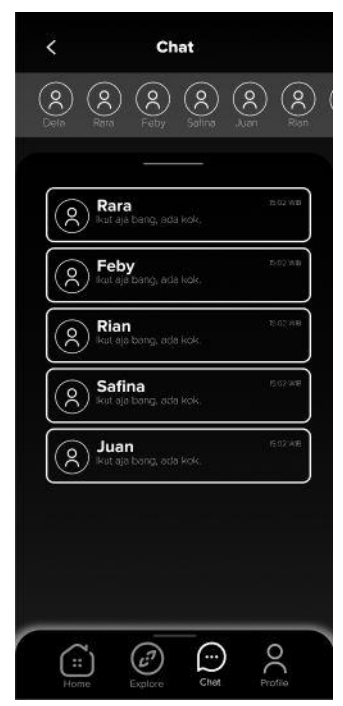

Gambar 9 Menu Utama Chat

Gambar 8 merupakan Menu Utama Profile. Dimenu ini user/musisi dapat melihat postingan yang diunggah oleh user/musisi lain, bahkan mereka juga dapat melihat event yang telah di favoritkan. Di kolom profil ini juga disediakan button chat untuk memudahkan pengguna dalam berkomunikasi jika ada informasi yang kurang jelas dari penyelenggara event melalui user yang telah memposting acaranya. Gambar 9 merupakan halaman chat dari aplikasi Kick Gigs. Widget atas adalah sebagai daftar kontak pengguna aplikasi Kick Gigs. Mereka dapat saling berinteraksi tanpa batasan.

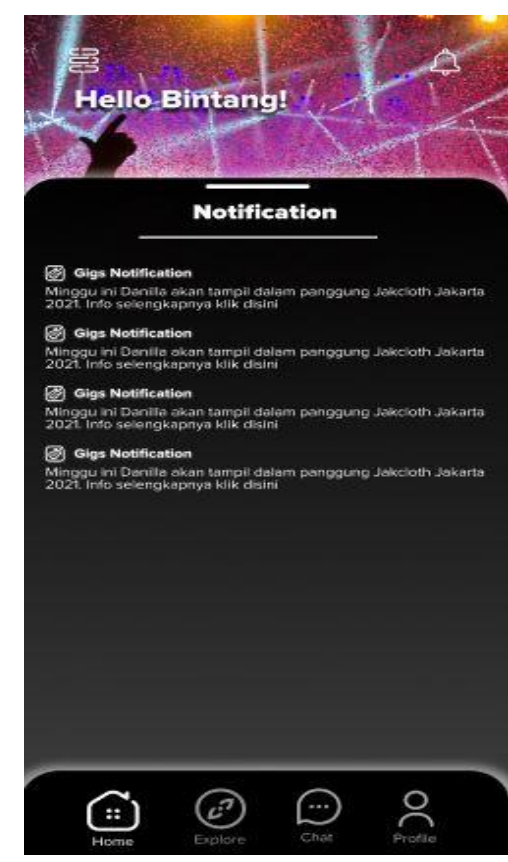

Gambar 10 Notification 
Gambar 10 merupakan Notifikasi. Notifikasi berisi informasi jadwal konser yang sebelumnya telah difavoritkan oleh pengguna. Notifikasi akan muncul saat 1 hari sebelum acara itu dimulai.

Kode Program 1 Add Event Pada Aplikasi Kick Gigs

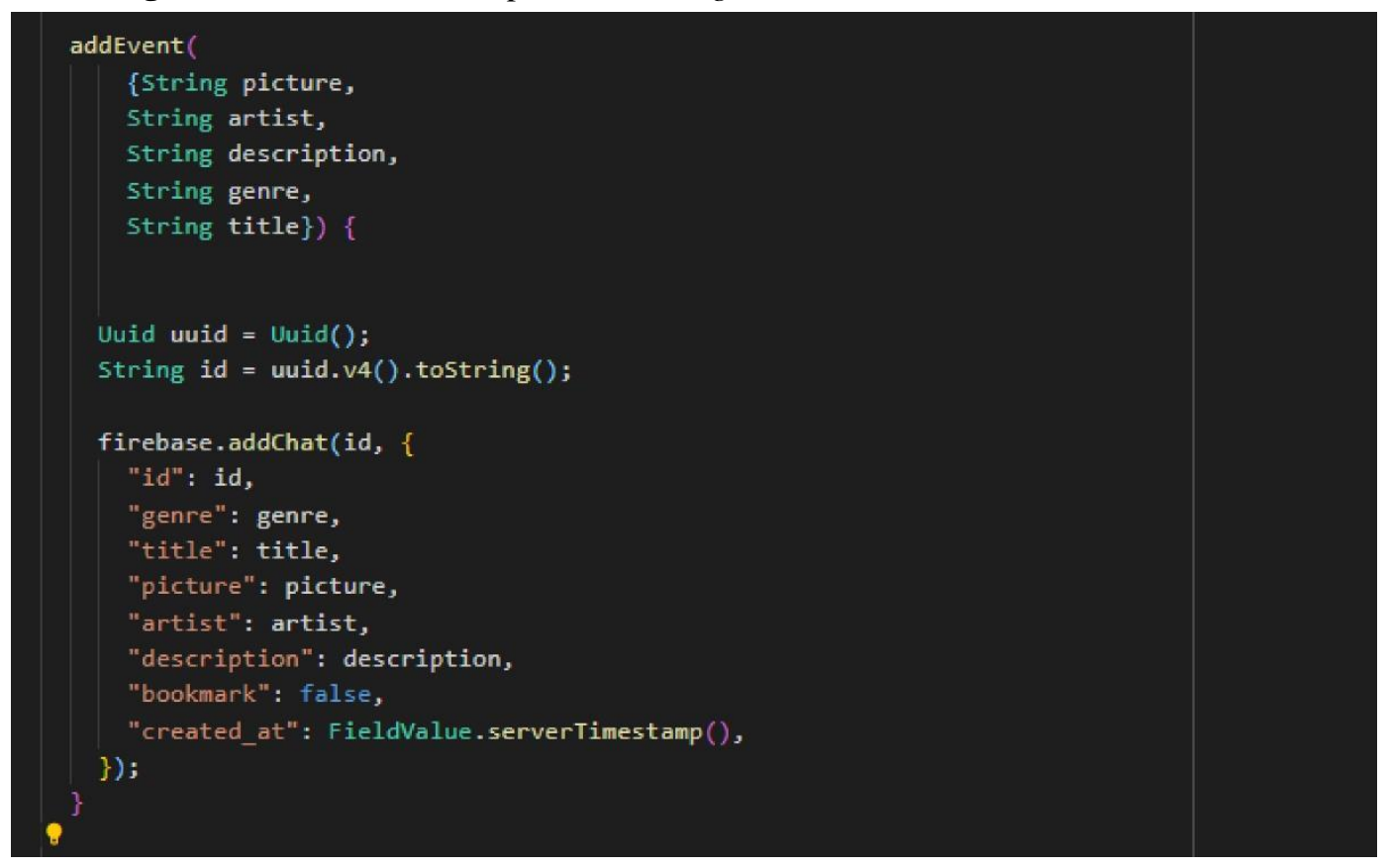

Pada Kode Program 1 merupakan kode untuk menjalankan fungsi Add Event. Setiap variable dapat memiliki nilai null \{String variable\}, sehingga user dapat memilih untuk tidak mengisi data sesuai field pada form yang nanti akan dijadikan informasi event. Lalu data yang telah dikirim ke firestore sesuai dengan data model yang tertera pada function. variable 'id' didapat dari generate ID oleh library package Uuid untuk menentukan ID secara dynamic setiap kali fungsi addEvent dijalankan, id yang ter-generate digunakan untuk pada firestore yang menentukan pemanggilan data query event, query data pada firestore juga dapat menyimpan link path seperti pada data variable String Picture untuk memanggil data path pada firebase storage nantinya. Lalu data yang telah dikirim ke firestore sesuai dengan data model yang tertera pada function. Misalnya di firestore terdapat data picture : "user/profile-picture/gambar.jpg" dari string akan di hit ke storage yang telah tersedia folder user ke folder profile-picture, untuk diambil link download ke gambar.jpg.

Tahapan terakhir adalah pengujian sistem yang dilakukan menggunakan black box testing. Pengujian pada suatu aplikasi bertujuan untuk memeriksa apakah sebuah program telah berjalan dengan semestinya atau masih ada kesalahan yang harus diperbaiki agar program yang dibuat akan menjadi program yang memiliki kualitas yang baik [12]. Software Testing adalah elemen kritis dari jaminan kualitas perangkat lunak yang merepresentasikan 
kajian pokok dari spesifikasi, desain, dan pengkodean. Peningkatan visibilitas (kemampuan perangkat lunak sebagai suatu elemen sistem dan "biaya" yang muncul akibat kegagalan perangkat lunak, dilakukannya perencanaan yang baik melalui pengujian yang teliti [13]. Hasil pengujian aplikasi mobile Kick Gigs yang dibuat dengan black box testing dapat dilihat Pada Tabel 1.

Tabel 1 Hasil Black Box Testing

\begin{tabular}{|c|c|c|c|c|}
\hline Fungsi Yang Diuji & Kondisi & Output Yang Diharapkan & Output Yang Dihasilkan & Status \\
\hline \multirow[t]{3}{*}{ Login } & $\begin{array}{l}\text { Email dan password } \\
\text { benar }\end{array}$ & $\begin{array}{l}\text { Sistem menerima akses } \\
\text { login lalu masuk ke } \\
\text { halaman menu utama }\end{array}$ & $\begin{array}{l}\text { Sistem menerima akses } \\
\text { login lalu masuk ke } \\
\text { halaman menu utama }\end{array}$ & Valid \\
\hline & Email salah & $\begin{array}{l}\text { Sistem menolak akses } \\
\text { login lalu menampilkan } \\
\text { pesan } \\
\text { "Couldn't find your } \\
\text { Google Account" }\end{array}$ & $\begin{array}{l}\text { Sistem menolak akses } \\
\text { login lalu menampilkan } \\
\text { pesan } \\
\text { "Couldn't find your } \\
\text { Google Account", }\end{array}$ & Valid \\
\hline & $\begin{array}{l}\text { Email benar dan } \\
\text { password salah }\end{array}$ & $\begin{array}{l}\text { Sistem menolak akses } \\
\text { login lalu menampilkan } \\
\text { pesan } \\
\text { "Wrong Password. Try } \\
\text { again or click Forgot } \\
\text { password to reset it" }\end{array}$ & $\begin{array}{l}\text { Sistem menolak akses } \\
\text { login lalu menampilkan } \\
\text { pesan } \\
\text { "Wrong Password. Try } \\
\text { again or click Forgot } \\
\text { password to reset it" }\end{array}$ & Valid \\
\hline Icon Home & $\begin{array}{ll}\text { Klik icon } & \text { Home } \\
\text { pada } & \text { Menu } \\
\text { Homepage. } & \end{array}$ & $\begin{array}{l}\text { Sistem menampilkan } \\
\text { Homepage berisi kolom } \\
\text { search Musisi, Tanggal } \\
\text { dan Previous Gigs Event }\end{array}$ & $\begin{array}{l}\text { Sistem berhasil } \\
\text { menampilkan data yang } \\
\text { telah diharapkan }\end{array}$ & Valid \\
\hline \multirow[t]{3}{*}{ Icon Explore } & $\begin{array}{lr}\text { Klik icon } & \text { Explore } \\
\text { pada } & \text { menu } \\
\text { Homepage } & \end{array}$ & \begin{tabular}{lrr} 
Sistem & \multicolumn{2}{r}{ menampilkan } \\
halaman explore & yang \\
berisi beranda & profil \\
musisi yang & telah \\
memposting & jadwal \\
panggungnya &
\end{tabular} & $\begin{array}{l}\text { Sistem berhasil } \\
\text { menampilkan nama user, } \\
\text { flyer event, judul, } \\
\text { tanggal acara, Icon } \\
\text { Favorit serta button See } \\
\text { More }\end{array}$ & Valid \\
\hline & Cek button See more & $\begin{array}{lr}\text { Sistem } & \text { berhasil } \\
\text { menampilkan } & \text { Detail } \\
\text { halaman Explore Detail }\end{array}$ & $\begin{array}{lr}\text { Sistem } & \text { berhasil } \\
\text { menampilkan } & \text { Detail } \\
\text { halaman explore detail }\end{array}$ & Valid \\
\hline & & $\begin{array}{l}\text { Event yang dipilih } \\
\text { berhasil di favoritkan dan } \\
\text { masuk ke halaman Profil }\end{array}$ & $\begin{array}{l}\text { Event yang dipilih } \\
\text { berhasil di favoritkan } \\
\text { dan masuk ke halaman } \\
\text { Profil }\end{array}$ & \\
\hline Icon Chat & $\begin{array}{l}\text { Klik Icon Chat pada } \\
\text { menu Homepage }\end{array}$ & $\begin{array}{l}\text { Sistem menampilkan } \\
\text { halaman chat }\end{array}$ & $\begin{array}{lr}\text { Sistem berhasil } \\
\text { menampilkan widget } \\
\text { daftar kontak dan kolom } \\
\text { chatting }\end{array}$ & Valid \\
\hline Icon Notification & $\begin{array}{ll}\text { Cek } & \text { button } \\
\text { Notification } & \end{array}$ & $\begin{array}{l}\text { Sistem menampilkan } \\
\text { Notification artist yang } \\
\text { telah di favoritkan. }\end{array}$ & $\begin{array}{l}\text { Sistem berhasil } \\
\text { menampilkan } \\
\text { Notification artist yang } \\
\text { telah di favoritkan } \\
\text { sebelumnya. }\end{array}$ & Valid \\
\hline Ubah Data User & $\begin{array}{l}\text { Form diisi dengan } \\
\text { benar }\end{array}$ & $\begin{array}{l}\text { Sukses tambah data dan } \\
\text { menampilkan pesan } \\
\text { "Data user berhasil } \\
\text { diubah" }\end{array}$ & $\begin{array}{l}\text { Sukses tambah data dan } \\
\text { menampilkan pesan } \\
\text { "Data user berhasil } \\
\text { diubah" }\end{array}$ & Valid \\
\hline
\end{tabular}




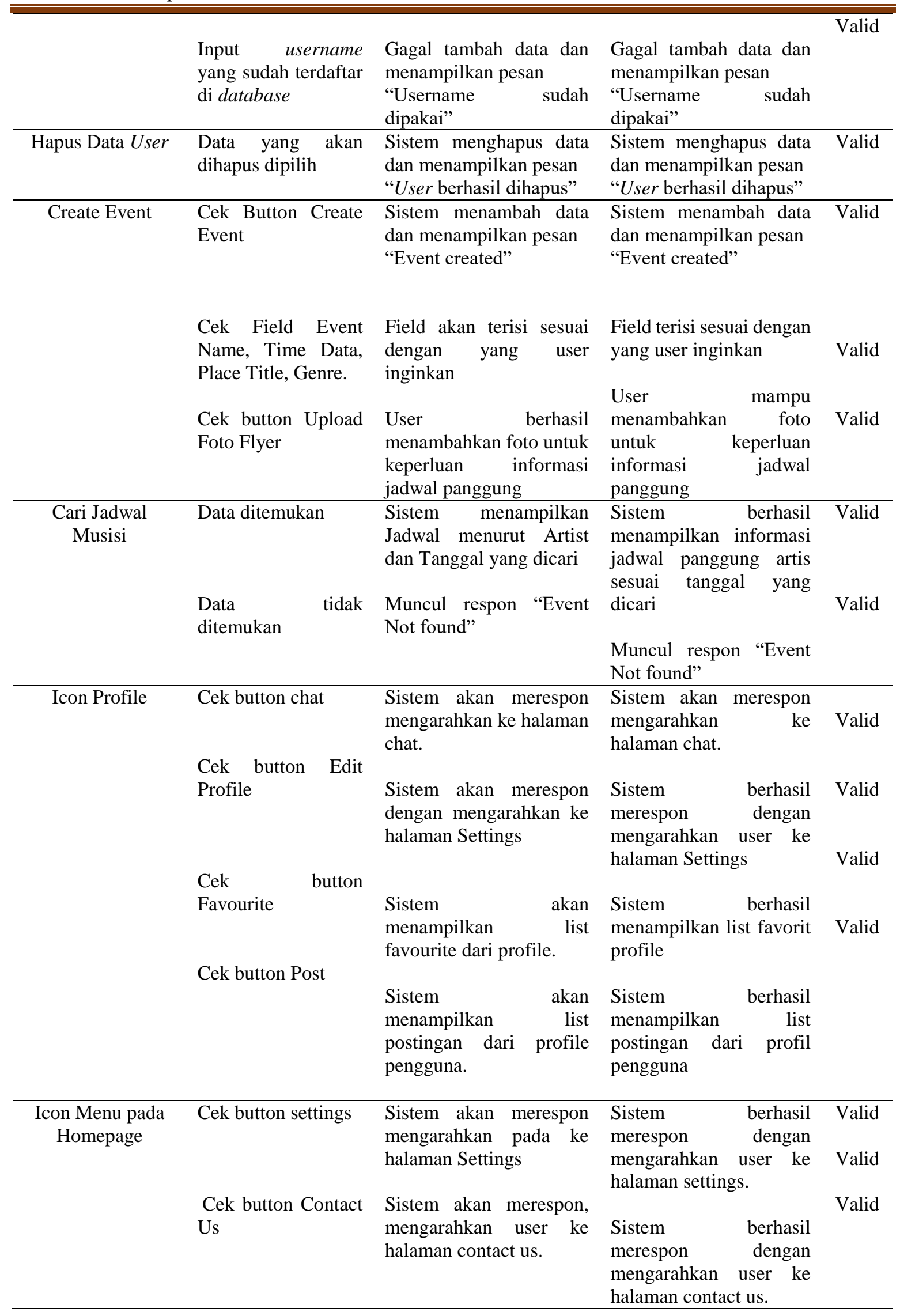




\section{SIMPULAN}

Penelitian ini menghasilkan Aplikasi Jadwal Konser bernama Kick Gigs berbasis mobile yang dapat berjalan sesuai dengan apa yang diharapkan yang dibangun menggunakan framework flutter dan basis data Firestore. Di dalam aplikasi jadwal konser ini, user sebagai musisi dapat melakukan pembuatan event dengan cepat dan mudah. Aplikasi Mobile ini diharapkan dapat membantu musisi kecil dalam pengembangan karir musiknya lebih baik lagi. Selain itu dapat membantu pengusaha cafe dan restoran untuk turut berdampingan bersama musisi dalam mengembangkan bisnis dan karya musik dengan pertunjukan live performance yang mengundang banyak pengunjung.

Saran dari penelitian ini yaitu dapat mengembangkan aplikasi ini dengan menambahkan fitur-fitur lain yang dapat terintegrasi dengan aplikasi mobile ini supaya dapat lebih lengkap, misalnya menambahkan fitur pemesanan tiket dengan pembayaran transfer lewat bank. Dengan adanya fitur tersebut diharapkan ekosistem musik di Indonesia semakin baik lagi.

\section{REFERENSI}

A. Ramadhanti, M. Nursaif, and A. M. I. Taufik, "Motivasi Penggunaan Spotify Sebagai Media Penyebarluasan Karya Musik Musisi Indie Lokal," Pros. Ind. Res. Work. Natl. Semin., vol. 10, no. 1, pp. 904-916, 2019.

Nawasasi Parantopo Haryo Prakoso, "Perlindungan Konsumen Terhadap Pembatalan Konser Musik Oleh Pihak Promotor," p. 2014, 2014, [Online]. Available: http://repository.unair.ac.id/13736/.

D. E. Vrenita and E. Sediyono, "Perancangan Aplikasi M-Market ( Mobile Market ) Berbahasa Jawa untuk Penjualan Smartphone ( Studi Kasus : Kota Salatiga )," no. 672013148, 2017.

T. A. S. Prasida, "Aplikasi Pengajuan Kredit Berbasis Android (Studi Kasus Bank Rakyat Indonesia Tondano).," 2012.

N. Maulana, T. A. S. Prasida, and A. H. Lasso, "Aplikasi Untuk Panduan Wisata Kuliner dengan SAW pada Android Mobile ( Studi Kasus : Kota Magelang )."

I. PUJI SAPUTRA, "Rancang Bangun Aplikasi Siska (Sistem Informasi Karier) Berbasis Android," J. Manaj. Inform., vol. 10, no. 2, pp. 21-28, 2020.

F. Enggar Krisnada and R. Tanone, "Aplikasi Penjualan Tiket Kelas Pelatihan Berbasis Mobile menggunakan Flutter," J. Tek. Inform. dan Sist. Inf., vol. 5, no. 3, pp. 281295, 2020, doi: 10.28932/jutisi.v5i3.1865.

G. W. Sasmito, "Penerapan Metode Waterfall Pada Desain Sistem Informasi Geografis Industri Kabupaten Tegal," J. Inform. Pengemb. IT, vol. 2, no. 1, pp. 6-12, 2017.

S. S. Vallery, Happy Novita, "UML Modeling and Black Box Testing Methods in the School Payment Information System,” J. Mantik, vol. 3, no. January, pp. 31-38, 2019. 
T. A. Kurniawan, "Pemodelan Use Case (UML): Evaluasi Terhadap beberapa Kesalahan dalam Praktik," J. Teknol. Inf. dan Ilmu Komput., vol. 5, no. 1, p. 77, 2018, doi: 10.25126/jtiik.201851610.

Ovi Marzuki, "Perancangan Sistem Informasi Pengelolaan Surat Perintah Membayar Pada Perum Peruri Berbasis Web Dengan Metode Pendekatan OBJECT ORIENTED ANALYSIS AND DESIGN (OOAD)," vol. 1, no. 1, pp. 41-57, 2019.

B. A. Priyaungga, D. B. Aji, M. Syahroni, N. T. S. Aji, and A. Saifudin, "Pengujian Black Box pada Aplikasi Perpustakaan Menggunakan Teknik Equivalence Partitions," $J$. Teknol. Sist. Inf. dan Apl., vol. 3, no. 3, p. 150, 2020, doi: 10.32493/jtsi.v3i3.5343.

G. W. Setiawan, "Pengujian Perangkat Lunak Menggunakan Metode Black Box Studi Kasus Exelsa Universitas Sanata Dharma,” p. 286, 2011, [Online]. Available: https://repository.usd.ac.id/32377/2/055314010_Full.pdf. 